\title{
Dorsiflexion and dynamic postural control asymmetry in elite male volleyball players
}

\section{Elit erkek voleybol oyuncularunda dorsifleksiyon ve dinamik postural kontrol asimetrisi}

\author{
Mutlu Cuğ ${ }^{*}{ }^{1}$, Erik A. Wilkstrom ${ }^{2}$, İbrahim Ethem Pak ${ }^{3}$, Güirkan Diker ${ }^{3}$
}

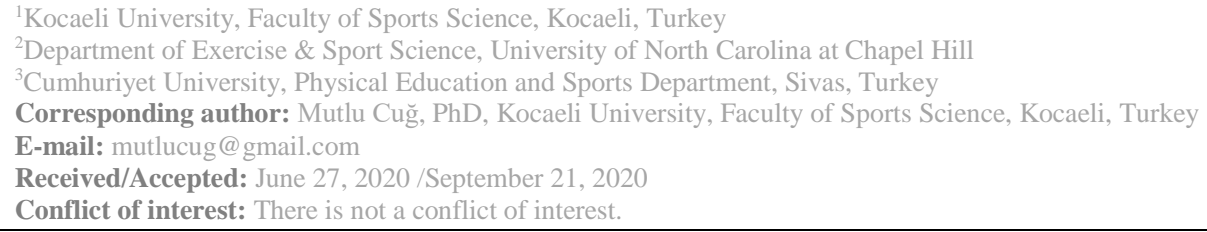

\section{SUMMARY}

Objective: Movement assymetry is considered a potential risk factor for musculoskeletal injury in sport. Sports such as volleyball are thought to cause movement assymetries due to specific sporting demands. Further, between limb comparisons are often used for return to sport decisions. Despite this, little information is available regarding the presence of assymetry in volleyball athletes. Therefore the purpose of this investigation was to determine the presence of assymetry in dorsiflexion range of motion (DFROM) and dynamic postural control variables, factors important in return to sport decisions, both the group and individual level in professional male volleyball players. Secondarly, we aimed to better understand the role of DFROM on the Star excursion balance test (SEBT), a measure of dynamic postural control.

Method: Thirty-two Professional male volleyball players (age: $24.7 \pm 5.53$ years, height: $190.6 \pm 7.63 \mathrm{~cm}$., weight: $84.5 \pm 9.28 \mathrm{~kg}$., BMI: $23.22 \pm 1.62$ $\mathrm{kg} / \mathrm{m}^{2}$ ) participated in this investigation. All participants reported for a single test session during which DFROM and the SEBT were assessed on both limbs.

Results: There was a significant group difference $(\mathrm{p}<0.05)$ between limbs for the normalized anterior (landing leg: $73.3 \pm 6.2 \%$; non-landing leg: 71.4 $\pm 6.8 \%$ ) posteromedial (landing leg: $112.6 \pm 9.3 \%$; non-landing leg: $107.6 \pm 10.8 \%$ ) and posterolateral (landing leg: $114.5 \pm 8.1 \%$; non-landing leg: $111.4 \pm 9.4 \%)$ SEBT reach direction. The anterior and posteriomedial but not the posteriolateral reach differences exceeded the minimal detectable change score for the SEBT. At the individual level, the vast majority of participants demonstrated minimal assymetry. Significant correlations were found between DFROM and the anterior SEBT reach $(\mathrm{r}=$ 0.36 to $0.39, \mathrm{p}<0.04)$ as well as the posteriolateral SEBT reach $(\mathrm{r}=0.47$ to $0.50, \mathrm{p}<0.01)$.

Conclusions: Professional volleyball players do not have DFROM or dynamic postural control assymetries but DFROM can influence dynamic postural control.

Keywords: Star Excursion Balance Test, weight bearing lunge, movement quality.

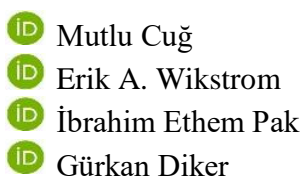

ORCID IDs of the authors: M.C. 0000-0002-1265-0073 E.A.W. 0000-0002-7260-0502 İ.E.P. 0000-0002-2599-9039 G.D. 0000-0003-0407-8238 
Amaç: Hareket asimetrisi kas/iskelet sistemi yaralanmalarında potansiyel bir risk faktörü olarak görülmektedir. Voleybol gibi bazı spor branşları sporun gerektirdiği özelliklerinden ötürü hareket asimetrisine yol açabilmektedir. Dahası, spora dönebilme kararının verilmesinde uzuvların karşılaştırması sıklıkla kullanılan bir yöntemdir. Buna rağmen, voleybolda asimetrinin varlığı ile ilgili çok sınırlı bilgi mevcuttur. Bu nedenle bu çalışmanın amacı, spora dönme kararının verilebilmesinde önemli olan ayak bileği dorsifleksiyon hareket açıklığı ve dinamik postural kontrol değerlerinde asimetrinin olup olmadığını hem bireysel olarak hem takım olarak değerlendirmekti. İkincil amaç olarak, ayak bileği hareket genişliğinin postural kontrol ölçümlerinde kullanılan Yıldız Gezinme Denge Testi (YGDT) üzerine olan etkisini daha iyi anlayabilmekti.

Yöntem: Otuz iki profesyonel erkek voleybolcu (yaş: $24.7 \pm 5.53$ yıl, boy: $190.6 \pm 7.63 \mathrm{~cm}$., vücut ağırlığı: $84.5 \pm 9.28 \mathrm{~kg}$. ve Beden Kitle İndeksi: $23.22 \pm 1.62 \mathrm{~kg} / \mathrm{m}^{2}$ ) çalışmamıza katılmıştır. Bütün katılımcıların her iki bacaklarının da ayak bileği hareket açıklıkları ve YGDT ölçümleri bir defada tamamlandı.

Bulgular: Yildız Gezinme Denge testinin normalize edilmiş anterior (yere iniş yapan ayak : $73.3 \pm 6.2 \%$; diğer ayak: $71.4 \pm 6.8 \%$ ), normalize edilmiş posteromedial (yere iniş yapan ayak : $112.6 \pm 9.3 \%$; diğer ayak: $107.6 \pm 10.8 \%$ ) ve normalize edilmiş posterolateral (yere iniş yapan ayak: $114.5 \pm 8.1 \%$; diğer ayak: $111.4 \pm 9.4 \%$ ) sonuçları arasında anlamlı bir fark bulunmuştur $(\mathrm{p}<0.05)$. Yıldız Gezinme Denge Testinde anterior ve posteromedial yönlerdeki farklar tespit edilebilir en düşük değeri geçerken posteriolateral yöndeki farkll1ık geçememiştir. Bireysel değerlendirmelerde ise katılımcıların çok büyük bir oranı minimal düzeyde bir asimetri sergilemişlerdir. Ayak bileği hareket açıklığı değeri ile Yildız Gezinme Denge Testinin anterior $(\mathrm{r}=0.36$ to $0.39, \mathrm{p}<0.04)$ ve posterolateral yönlerdeki $(\mathrm{r}=0.47$ to $0.50, \mathrm{p}<0.01)$ uzanımları arasında anlamlı korelasyon bulunmuştur.

Sonuç: Profesyonel voleybol oyuncularının ne ayak bileği hareket açıklıklarında ne de dinamik postural kontrol değerlerinde asimetrilik söz konusu değildir. Bununla birlikte ayak bileği hareket açıklığı dinamik postural kontrolü etkilemektedir.

Anahtar sözcükler: Yıldız gezinme denge testi, vücut ağırlığı bindirilen hamle hareketi, hareket kalitesi.

\section{INTRODUCTION}

Movement asymmetry is considered a risk factor for initial and recurrent musculoskeletal injury. ${ }^{1}$ However, select sports such as volleyball, tennis, and basketball are known to cause between limb movement asymmetries in a variety of outcomes including strength, coordination, and neuromuscular control due to the specific demands of the sport. ${ }^{2-7}$ Additionally, past and present musculoskeletal injuries can lead to movement asymmetries. ${ }^{8}$ Both sport and injury induced asymmetry is problematic for sport scientists and medical providers because an athlete's contralateral limb is often used as a reference when assessing injury risk, monitoring rehabilitation progress, and/or making return to sport decisions. However, movement symmetry is often assumed to be present before injury ${ }^{9}$ and regardless of sport. As a result, the identification and correction of movement asymetries has been a major concern of sport scientists and medical providers in recent years.

Unfortunately, there remains a derth of information about asymmetries in competitive athlets, especially those participating in sports known to cause movement asymmetries (e.g. volleyball). Further, the existing evidence has focused on the presence of asymetries entireley from a group perspective (i.e. mean differences) while ignoring individual level analyses (e.g. level of agreement). The most common musculoskeletal injury in volleyball is a lateral ankle sprain. ${ }^{10}$ This injury is known to limit both dorsiflexion range of motion $(\mathrm{DROM})^{11}$ and dynamic postural control as measured via the Star Excursion Balance Test (SEBT). ${ }^{12,13}$ Thus, normative asymmetry data in uninjured volleyball athletes would help determine 1) how much asymmetry is normal in this population, and 2) provide a reference as to when an athlete may be ready to return to sport following an injury.

Further, a growing body of research has demonstrated a relationship between DFROM, measured via the weight bearing lung test (WBLT), and the anterior reach of the SEBT in those with and without a history of lateral ankle sprains. ${ }^{11}$ However, these relationships have only been explored in recreational athletes and within a singular limb. As a result, it is unclear how a DFROM asymmetry influences SEBT asymmetry in higher level volleyball athletes. Understanding how one asymmetry influences another has the potential to enhance treatment paradigms and clinical decision making.

Therefore, the primary purpose of this investigation was to determine the magnitude of DFROM and dynamic postural control asymmetry in male volleyball players at a group and individual level. We hypothesized that both group and individual analyses would demonstrate dynamic postural control but not DFROM asymmetries in professional male volleyball players. Our 
secondary purpose was to further investigate the relationship between DFROM and normalized SEBT reach distances. We hypothesized that in both limbs, the anterior SEBT reach distance would be associated with the ipsilateral DFROM. Further, we hypothesized that the magnitude of DFROM asymmetry would associate with the magnitude of anterior SEBT asymmetry.

\section{MATERIAL AND METHODS}

\section{Participants}

Thirty-two male volleyball players (age: $24.7 \pm 5.53$ years, height: $190.6 \pm 7.63 \mathrm{~cm}$., weight: $84.5 \pm 9.28 \mathrm{~kg}$., BMI: $23.22 \pm 1.62 \mathrm{~kg} / \mathrm{m}^{2}$ ) who played in the first and second divisions of the "Turkish Volleyball League" in 2012-2013 or 2016-2017 season participated in this investigation. All participants were required to (1) have no history of lower extremity injury in either leg within the last six months, (2) be free of cerebral concussions and vestibular disorders, (3) be free of cardiovascular and metabolic disorders, (4) have no history of serious lower extremity surgery. Twenty-six of the 32 participants were right hand and left leg dominant. Leg dominance refers to the limb that participants would typically land on during a volleyball maneuver.

\section{Procedures}

Prior to participation, all participants provided written informed consent, which was approved by the Cumhuriyet University Institutional Review Board (2013-07/01) prior to participation. All participants reported for a single test session during which ankle DFROM and dynamic postural control, measured via the WBLT and SEBT respectively, were assessed on both limbs. The order of the assessment (WBLT and SEBT) and limb completion were counterbalanced across participants.

The weight bearing lunge test (WBLT), as described by Bennell et al. was used to quantify ankle DFROM. ${ }^{14}$ In brief, the WBLT was performed while standing barefoot with the participants' foot and knee positioned in a plane perpendicular to a wall. Participants could touch the wall during the test to maintain their balance and the non-test limb could rest in a comfortable position on the floor behind the test limb. Participants lunged forward until the ipsilateral knee contacted the wall without raising the corresponding heel from the floor. Participants then progressively moved their test foot backwards, away from the wall in $1 \mathrm{~cm}$ increments, before repeating the test procedure until maximum ankle DFROM was obtained. Maximum DFROM was quantified as the furthest distance, in $\mathrm{cm}$, between the great toe and the wall when the knee was in contact with the wall and the heel remained on the ground. Three test trials were collected for each limb. Each average was used for further analysis and to calculate DFROM asymmetry.

Three SEBT directions (anterior, posteriomedial, posterolateral) were performed barefoot for each limb. ${ }^{15}$ Participants were asked to place their great toe at the center of the grid for all directions. Participants were then instructed to reach as far as possible with their non-stance limb while keeping their balance and their hands-on hips throughout the task (i.e. reach and return to start position). Reach distance was recorded as the furthest point the non-stance foot was able to touch without transferring weight onto the non-stance limb. Prior to completing three test trials per limb, each participant completed six practice attempts in each direction, on each limb ${ }^{16}$ to minimize potential learning effects. Direction order was randomized for each participant. Leg length, operationally defined as the distance, in $\mathrm{cm}$, between the anterior superior iliac spine (ASIS) and the distal end of the ipsilateral medial malleolus was measured and used to normalize reach distances. The three trial average for each limb was used for data analysis and to calculate between-limb asymmetry.

To assess group level asymmetry, independent sample t-tests compared mean DFROM and SEBT differences between limbs. Between limb differences were then compared to previously established minimal detectable change scores: SEBT-Ant: $1.81 \%$; SEBT-PM: $3.16 \%$; SEBT-PL: $5.25 \%$, DFROM: $0.34 \mathrm{~cm} .{ }^{17}$ To asses individual level asymmetry (i.e. assess systematic side biases), Bland-Altman analyses were performed for each variable. To assess the association between DFROM and normalized SEBT reach distances, Pearson correlation coefficients were used. Associations were assessed for the (1) landing limb, (2) non-landing limb, and (3) between limb asymmetry. An a priori alpha level was set at $\mathrm{p}<0.05$ for all statistical analyses and analyses were performed with SPSS Version 19.0.

\section{RESULTS}

Group means, standard deviations, mean differences, minimal detectable change scores for the primary dependent variables can be seen in Table 1. Significant between limb differences $(p<0.01)$ were noted for the anterior, posteromedial and posterolateral SEBT reach direction, with the landing limb demonstrating better balance. Further, the magnitude of the SEBT-Ant and SEBT- PM, but not the SEBT-PL, between limb 
differences exceeded established MDC scores for these variables (i.e. the magnitude of difference was greater than the error typically associated with the measures in question). No group level difference in DFROM was noted ( $p>0.05)$.

However, at the individual level, the Bland Altman analyses revealed no directional asymmetries in any of the dependent variables (Figure 1). In brief, $87.5 \%$ (28 of 32) of participants had DFROM asymmetries $<1$ standard deviation from the mean. Similarly, $93.75 \%$ (30 of 32), 100\% (32 of 32), and
$96.88 \%$ (31 of 32) of the participants had SEBTAnt, SEBT-PM, and SEBT-PL asymmetries <1 standard deviation from the mean, respectively.

The DFROM outcome was moderately associated with the anterior and posterolateral normalized SEBT reach distance on the landing and nonlanding limb (Table 2). However, the between limb DFROM asymmetry did not associate with the between limb asymmetry for any of the dynamic postural control reach distances.

Table 1: Dorsiflexion range of motion and dynamic postural control scores for each limb.

\begin{tabular}{|l|c|c|c|c|c|}
\hline & Non-landing & Landing & $p$ & $\begin{array}{c}\text { Mean } \\
\text { difference }\end{array}$ & $\begin{array}{c}\text { MDC for } \\
\text { reference } \\
\text { standard }\end{array}$ \\
\hline Anterior (\%) & $71.4 \pm 6.8$ & $73.3 \pm 6.2$ & $<0.01^{*}$ & -1.92 & $1.81^{17}$ \\
\hline $\begin{array}{l}\text { Posteromedial } \\
(\%)\end{array}$ & $107.6 \pm 10.8$ & $112.6 \pm 9.3$ & $<0.01^{*}$ & -5.02 & $3.16^{17}$ \\
\hline $\begin{array}{l}\text { Posterolateral } \\
(\%)\end{array}$ & $111.4 \pm 9.4$ & $114.5 \pm 8.1$ & $<0.01^{*}$ & -3.05 & $5.25^{17}$ \\
\hline $\begin{array}{l}\text { Ankle DFROM } \\
(\mathrm{cm})\end{array}$ & $13.5 \pm 2.7$ & $13.6 \pm 2.37$ & 0.86 & -0.04 & $1.90^{24}$ \\
\hline
\end{tabular}

* indicates significant differences between limbs $\mathrm{p}=0.05$,

MDC: Minimal Detectable Change

Table 2: Correlations among dorsiflexion range of motion and dynamic postural control scores for the individual limbs and for beween limb asymmetries.

\begin{tabular}{|l|l|l|l|l|}
\hline & & SEBT-Ant & SEBT-PM & SEBT-PL \\
\hline Nonlanding limb & DFROM & $.359^{*}$ & .224 & $.472^{*}$ \\
\hline Landing limb & DFROM & $.397^{*}$ & .268 & $.502^{*}$ \\
\hline Between limb asymmetry & DFROM & .284 & .030 & .140 \\
\hline
\end{tabular}

\footnotetext{
* Indicates a statistically significant correlation ( $<<0.044)$. DFROM: dorsiflexion range of motion, SEBT: star excursion balance test, Ant: anterior, PM: posteomedial, PL: posteriolateral
} 

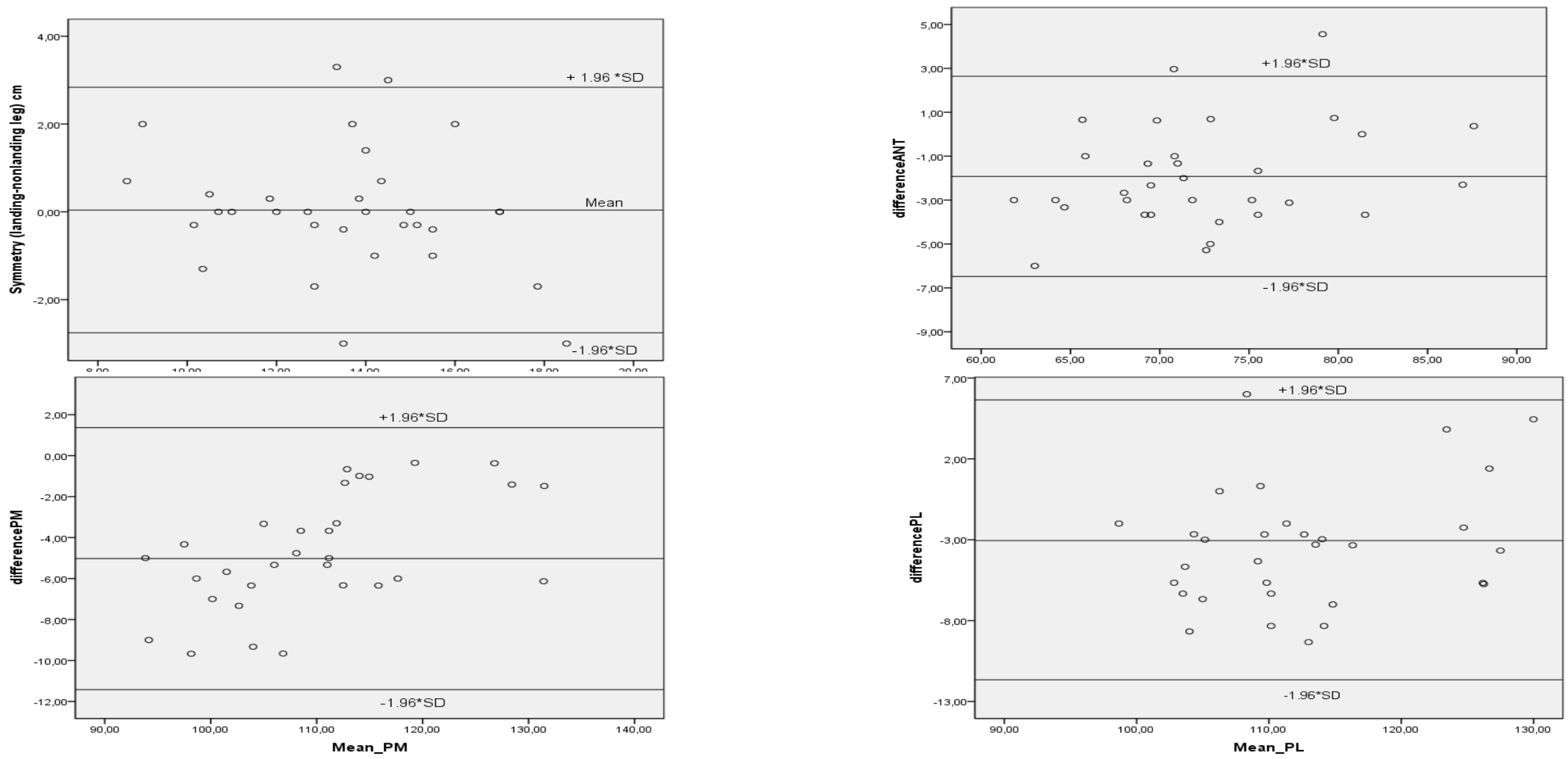

Figure 1: Bland - Altman plot indicating the lunge distance asymmetry, SEBT-Ant, SEBT-PM, SEBT-PL reaching distance between the landing and nonlanding legs of healthy adults. Each participant is represented as an " o " mark. Solid lines indicates the upper and lower bounds of the 95\% confidence interval 


\section{DISCUSSION}

The primary aim was to determine the magnitude of DFROM and dynamic postural control asymmetry in male volleyball players at a group and individual level. Our main DFROM finding was a lack of asymmetry in high level male volleyball athletes based on both group and individual level analyses, consistent with our hypothesis. Our main dynamic postural control findings were contrary to each other. More specifically, we noted significant between group differences and some these differences (SEBT-Ant, SEBT-PM) exceeded previously calculated MDC scores. However, Bland-Altman plots demonstrated a lack of asymmetry at the individual level, in all SEBT reach directions, contrary to our a priori hypothesis. Our secondary aim was to further investigate the relationship between DFROM and normalized SEBT reach distances. Our results demonstrate moderate associations between DFROM and anterior SEBT reach distances for each limb. This finding supports our a priori hypothesis and is consistent with the existing literature.

To our knowledge, this is the first investigation to examine the relationship between DFROM and SEBT reach distance in higher level athletes. As such, it is important to note how our sample of professional volleyball athletes DFROM and SEBT performance compares to healthy individuals and high-level athletes. For example, our DFROM means are slightly higher than those previously reported for a group of uninjured healthy adults (right : $12.0 \pm 2.8 \mathrm{~cm}$, left: $11.9 \pm 2.8$ $\mathrm{cm}$ ) who were not high level athletes. ${ }^{18}$ Similarly, our normalized SEBT reach distance means are similar to those previously reported in collegiate basketball players [Ant (74\%), PM (108\%), and PL (100\%)]. ${ }^{19}$

\section{Between Limb Asymmetry}

Highly skilled volleyball attackers, can practice 1620 hours a week and perform about 40,000 spikes a year. ${ }^{20}$ These maneuvers often result in unilateral landings ${ }^{21}$ and thus the landing limb has an increased need for explosive strength and coordination. ${ }^{3,22}$ This hypothesis is supported by noted asymmetries in landing biomechanics (e.g. knee joint abduction angle, the internal adductor joint moment and vertical ground reaction force magnitude) and strength in high level volleyball athletes. 5, 23 While it is unknown if such asymmetries were present in the current cohort. If such asymmetries were present, they did not translate to meaningful asymmetries in DFROM or dynamic balance at the individual level.
Previous research has established the MDC for the WBLT and suggested that a WBLT difference 1 or $2 \mathrm{~cm}$ appears to be a normal between limb difference. ${ }^{18}$ Further, the minimal detectable change of the WBLT has been established to be between 1.6 and $1.9 \mathrm{~cm} .{ }^{24}$ Cumulatively, these results would suggest that $\mathrm{a} \geq 2 \mathrm{~cm}$ difference is representative of a meaningful DFROM asymmetry. Based on the current cohort, no DFROM, as measured via the WBLT, exists at the group level as a mean asymmetry of $0.04 \mathrm{~cm}$ was observed. At the individual level, only $22 \%(n=7)$ of the current cohort demonstrated an asymmetries $\geq 2 \mathrm{~cm}$. At this time, the cause of this minimal asymmetry remains unclear but soft tissue and/or arthrokinematic limitations may play a role. While DFROM appears symetrical in high level male volleyball players, the cumulative research would suggest that these these athletes may use the available ROM differently between limbs. While speculative this hypothesis is supported by the biomechanical and neuromuscular control differences previously reported between limbs ${ }^{25}$ as well as the between limb group differences observed in the SEBT reach distances. However, such differences were not observed at the individual level and thus dictate further research about the meaningfulness of group level asymmetry calculations..

Greater dynamic postural control, as measured by the SEBT, requires a combination of balance, strength, neuromuscular control, and range of motion. ${ }^{26}$ Further, between limb asymmetries ranging from $3-8 \%$ have been noted in collegiate athletes ${ }^{27}$ and previous research has suggested that a posteriorlateral between limb difference exists in high level youth soccer players. ${ }^{28}$ These results are consistent with the current group level differences observed in all three SEBT reach directions. When such scores are taken into account, meaningful asymmetry does not exist in any of the reported cohorts. However, our current SEBT-Ant and SEBT-PM results did consider the between limb difference in the context of established MDC scores and our calculated differences exceeded the calculated MDC scores. These results would suggest a meaningful between limb group dynamic postural control differences in high level male volleyball players.

However, in the current cohort, less than $10 \%$ of individual participants demonstrated a between limb dynamic posutal control difference greater than one standard deviation on any of the SEBT Bland-Altman plots. Cumulatively, these individual results are consistent with research demonstrating no between limb SEBT differences 
in elite male soccer players. ${ }^{29}$ The contrary results of group and individual differences highlights a statistical delimma for sports sciences and healthcare providers as small, and apparently nonmeaningful between limb differences generate group differences with large enough sample sizes.

\section{DFROM and SEBT Associations}

Multiple investigations have demonstrated that DFROM influences the anterior SEBT reach distance. ${ }^{11}$ For example, one investigation reported a moderate $(\mathrm{r}=0.53)$ association between these variables. ${ }^{11}$ While associations for both limbs were noted in the current investigation, the strength of the single limb associations were not as strong as those previously reported. However, our between limb DFROM asymmetry did not associate with between limb dynamic postural control asymmetries. Cumulatively, these results reinforce the role of DFROM on ipsilateral anterior SEBT reach distances.

We also observed associations between DFROM and the posteriolateral reach distance on both limbs. While consistent with the existing literature, our associations were much stronger than those previously reported $(\mathrm{r}=0029) .{ }^{30}$ However, the between limb DFROM difference did not influence the between limb posteriolateral SEBT reach distance. This result may suggest that while DFROM plays an important role, the limbs use different motor control strategies to coordinate posteriolateral SEBT reach performance.

\section{CONCLUSION}

Uninjured high level male volleyball players do not have DFROM asymmetries. Dynamic postural control asymmetries are observed when group level but not individual level analyses are conducted. Our results further support the importance of DFROM for SEBT performance, particularly in the posteriolateral and anterior reach direction.

\section{Acknowledgments}

We would like to thank to Nazlı Erdoğan and coaches (Levent Zoroğlu and Savaş Akkaya) and players of Sivas 4 Eylül Belediyespor Volleyball Club, TKD Kuzey Enerji Gümüşhane Torul Gençlik Volleyball Club and, Erzurum Palandöken Belediye Volleyball Club for their participation in this investigation.

\section{REFERENCES}

1. Paterno MV, Ford KR, Myer GD, Heyl R, Hewett TE. Limb asymmetries in landing and jumping 2 years following anterior cruciate ligament reconstruction. Clinical Journal of Sport Medicine 2007; 17: 258-62.
2. Castanharo R, Orselli MIV, Alcantara C, Miana $\mathrm{Ai}$, de Jesus Manoel E, ProenÃ $§ a ~ J E$, et al. ASYMMETRIES BETWEEN LOWER LIMBS DURING JUMPING IN FEMALE ELITE ATHLETES FROM THE BRAZILIAN NATIONAL VOLLEYBALL TEAM. In: ISBS-Conference Proceedings Archive. 2011.

3. Tillman MD, Hass CJ, Brunt D, Bennett GR. Jumping and Landing Techniques in Elite Women's Volleyball. Journal of sports science and medicine 2004; 3: 30-6.

4. Markou S, Vagenas G. Multivariate isokinetic asymmetry of the knee and shoulder in elite volleyball players. European Journal of Sport Science 2006; 6: 71-80.

5. Castanharo R, Orselli MIV, Alcantara C, Miana A, de Jesus Manoel E, Proença JE, et al. Asymmetries between lower limbs during jumping in female elite athletes from the brazilian national volleyball team. In: ISBSConference Proceedings Archive. 2011.

6. Rogowski I, Ducher G, Brosseau O, Hautier C. Asymmetry in volume between dominant and nondominant upper limbs in young tennis players. Pediatric Exercise Science 2008; 20: 263-72.

7. Schiltz M, Lehance C, Maquet D, Bury $T$, Crielaard JM, Croisier JL. Explosive Strength Imbalances in Professional Basketball Players. Journal of Athletic Training 2009; 44: 39-47.

8. Rocheford EC, DeVoe DE, Reiser R. Effect of previous unilateral injuries on ground reaction force bilateral asymmetries during static lifting and standing. Journal of Human Movement Studies 2006; 51: 403-24.

9. Clifford AM, Holder-Powell H. Postural control in healthy individuals. Clinical Biomechanics 2010; 25: 546-51.

10.Reeser JC, Verhagen E, Briner WW, Askeland TI, Bahr R. Strategies for the prevention of volleyball related injuries. British Journal of Sports Medicine 2006; 40: 594-U20.

11.Hoch MC, Staton GS, McKeon PO. Dorsiflexion range of motion significantly influences dynamic balance. Journal of Science and Medicine in Sport 2011; 14: 90-2.

12.Evans T, Hertel J, Sebastianelli W. Bilateral deficits in postural control following lateral ankle sprain. Foot \& Ankle International 2004; 25: 833-9.

13.Wikstrom EA, Naik S, Lodha N, Cauraugh JH. Balance Capabilities after Lateral Ankle 
Trauma and Intervention: A Meta-analysis. Medicine and Science in Sports and Exercise 2009; 41: 1287-95.

14.Bennell K, Talbot $\mathrm{R}$, Wajswelner $\mathrm{H}$, Techovanich W, Kelly D, Hall AJ. Intra-rater and inter-rater reliability of a weight-bearing lunge measure of ankle dorsiflexion. Australian Journal of physiotherapy 1998; 44: 175-80.

15.Plisky PJ, Rauh MJ, Kaminski TW, Underwood FB. Star Excursion Balance Test as a predictor of lower extremity injury in high school basketball players. Journal of Orthopaedic \& Sports Physical Therapy 2006; 36: 911-9.

16. Hertel J, Miller SJ, Denegar CR. Intratester and intertester reliability during the Star Excursion Balance Tests. Journal of Sport Rehabilitation 2000; 9: 104-16.

17.Hoch MC, McKeon PO. Joint mobilization improves spatiotemporal postural control and range of motion in those with chronic ankle instability. Journal of Orthopaedic Research 2011; 29: 326-32.

18. Hoch MC, McKeon PO. Normative range of weight-bearing lunge test performance asymmetry in healthy adults. Manual therapy 2011; 16: 516.

19.Potters H, Miller J, Wilson K. Changes in SEBT Scores in College Basketball Players Participating in a Preventative Ankle Program. Journal of Sports Medicine and Allied Health Sciences: Official Journal of the Ohio Athletic Trainers Association 2018; 4: 22.

20.Kugler A, Kruger-Franke M, Reininger S, Trouillier HH, Rosemeyer B. Muscular imbalance and shoulder pain in volleyball attackers. British Journal of Sports Medicine 1996; 30: 256-9.

21.Tillman MD, Criss RM, Brunt D, Hass CJ. Landing Constraints Influence Ground Reaction Forces and Lower Extremity EMG in Female Volleyball Players. Journal of Applied Biomechanics 2004; 20.
22.Calbet JAL, Herrera PD, Rodriguez LP. High bone mineral density in male elite professional volleyball players. Osteoporosis international 1999; 10: 468-74.

23.Markou S, Vagenas G. Multivariate isokinetic asymmetry of the knee and shoulder in elite volleyball players. European Journal of Sport Science 2006; 6: 71-80.

24.Powden CJ, Hoch JM, Hoch MC. Reliability and minimal detectable change of the weightbearing lunge test: a systematic review. Manual therapy $2015 ; 20: 524-32$.

25.Lobietti R, Coleman S, Pizzichillo E, Merni F. Landing techniques in volleyball. Journal of Sports Sciences 2010; 28: 1469-76.

26.Hertel J, Miller SJ, Denegar CR. Intratester and intertester reliability during the Star Excursion Balance Tests. Journal of sport rehabilitation 2000; 9: 104-16.

27.Stiffler MR, Sanfilippo JL, Brooks MA, Heiderscheit BC. Star Excursion Balance Test performance varies by sport in healthy division I collegiate athletes. Journal of Orthopaedic \& Sports Physical Therapy 2015; 45: 772-80.

28.Gkrilias P, Zavvos A, Fousekis K, Billis E, Matzaroglou C, Tsepis E. Dynamic balance asymmetries in pre-season injury-prevention screening in healthy young soccer players using the Modified Star Excursion Balance Test-a pilot study. Journal of physical therapy science 2018; 30: 1141-4.

29.Onofrei R-R, Amaricai E, Petroman R, Surducan D, Suciu O. Preseason Dynamic Balance Performance in Healthy Elite Male Soccer Players. American journal of men's health 2019; 13: 1557988319831920.

30.Basnett CR, Hanish MJ, Wheeler TJ, Miriovsky DJ, Danielson EL, Barr J, et al. Ankle dorsiflexion range of motion influences dynamic balance in individuals with chronic ankle instability. International journal of sports physical therapy 2013; 8: 121. 